\title{
Remember, Celebrate, and Forget? The Martin Luther King Day and the Pitfalls of Civil Religion
}

\author{
JANA WEISS
}

2016 marked the twentieth anniversary of the establishment of the Martin Luther King Day, which honors the civil rights leader and recognizes the contributions of African Americans. However, the holiday has also become a day of debate over King's legacy and, in turn, over the (mis) use of the nation's civil religion. On the one hand, the civil religious narrative of enduring unity, of the Promised Land, and of King as the nation's redeemer, which evolved around the implementation of the holiday during the 1970 s and early 1980 , appealed to a broad audience and forged a sense of unity. On the other hand, it also masked real progress and lead to a symbolic "pseudo-integration" of African Americans. Hence, as the ideals of the Declaration of Independence seemed to be finally achieved, it is not surprising that King has been succcessfully turned into a poster boy against affirmative action.

Dead men make such convenient heroes;

They cannot rise to challenge the images we would fashion from their lives; And besides, it is easier to build monuments than to make a better world. ${ }^{1}$

Since 1986 Americans of all races and backgrounds annually honor Rev. Dr. Martin Luther King Jr. on the third Monday in January. ${ }^{2}$ The day is celebrated by whites and blacks, Republicans and Democrats, with diverse activities such as parades, church services, vigils, concerts and various events to commemorate King's life and legacy - "truly a prophetic voice [who] challenged us to make real the promise of America as a land of freedom, equality, opportunity, and

History Department, Westfalische Wilhelms-Universität Münster. Email: weissjana@unimuenster.de.

${ }^{I}$ Carl Wendell Himes Jr. (1970), cited in Ira G. Zepp and Melvyn D. Palmer, eds., Drum Major for a Dream: Poetic Tributes to Martin Luther King, Jr. (Thompson, CT: InterCulture Associates, 1976), 23.

${ }^{2}$ Note that in some states the holiday was implemented earlier (e.g. in Illinois in 1973). By I 992 every state had established a holiday in King's honor. Yet even today in some states the day is recognized rather ironically, e.g. Arkansas and Alabama celebrate King together with Robert E. Lee, Civil War general of the Confederacy. See Becky Little, "The Controversial History of Martin Luther King," National Geographic Online, I 3 Jan. 20 17, at http://news. nationalgeographic.com/2017/o / martin-luther-king-jr-day-robert-e-lee-birthday-holiday. 
brotherhood ... 'guided by the deepest principles of our Christian faith'," as President Ronald Reagan proclaimed in 1986.3

However, while a national holiday is the highest honor a nation can confer upon one of its citizens, King's legacy continues to be a source of debate: by focussing on one line of his "I Have a Dream" speech, King has been molded into "a gentle champion of colorblindness," a useful instrument in the battle against affirmative action, as historian Jason Sokol recently declared in the New York Times. ${ }^{4}$ And the holiday, as Sokol maintains, is "both cause and effect of this selective appropriation." The present article argues that it is not the holiday per se, but more specifically the holiday's civil religious symbolism, that has caused this appropriation. As King himself had used civil religion as a powerful tool to garner support and legitimize the civil rights agenda, it became a key instrument in the drive for the official implementation of a day in his honor in the I 970 s and early I 980 os. However, ultimately, the use of civil religion led to a kind of pseudo-integration of African Americans, which actually hampered progress.

Surprisingly, studies on minority groups and their relation to American civil religion are rare, 5 especially in comparison to the wealth of studies on King and the interplay of religion, politics, and race. ${ }^{6}$ One exception is David HowardPitney's dissertation, which deals with King's rhetoric as a reflection of the African American jeremiad and civil religion. ${ }^{7}$ Moreover, some of the articles

${ }^{3}$ Ronald Reagan ( 18 Jan. 1986), "Proclamation 543 I - Martin Luther King, Jr. Day," in Gerhard Peters and John T. Woolley, eds., The American Presidency Project (hereafter $A P P)$, at www.presidency.ucsb.edu.

${ }^{4}$ Jason Sokol, "Which Martin Luther King Are We Celebrating Today?", New York Times Online, I6 Jan. 2017, at www.nytimes.com/2017/01/16/opinion/which-martin-lutherking-are-we-celebrating-today.html.

5 Cf. Charles H. Long, "Civil Rights - Civil Religion: Visible People and Invisible Religion," in Russel E. Richey and Donald G. Jones, eds., American Civil Religion (New York: Harper \& Row, I 974), 2 I I-2 I; Spencer Bennett, "Civil Religion in a New Context: The MexicanAmerican Faith of Cesar Chavez," in Gustavo Benavides and M. W. Daly, eds., Religion and Political Power (Albany: State University of New York Press, 1989), I 5 I-66.

${ }^{6}$ Cf. Steven F. Lawson, "Freedom Then, Freedom Now: The Historiography of the Civil Rights Movement," American Historical Review, 96, 2 (1991), 456-71; Taylor Branch, America in the King Years, 3 vols. (New York: Simon and Schuster, 1982-2006); David J. Garrow, Martin Luther King, Jr., and the Civil Rights Movement, i 8 vols. (New York: Carlson Publishing, 1989); Stewart Burns, To the Mountaintop: Martin Luther King, Jr.'s Sacred Mission to Save America, I955-Ig68 (San Francisco: Harper, 2004); Mark Noll, God and Race in American Politics: A Short History (Princeton, NJ: Princeton University Press, 2008).

7 David Howard-Pitney, The African-American Jeremiad: Appeals for Justice in America (Philadelphia: Temple University Press, 2005; first published 1990); Howard-Pitney, "“To Form a More Perfect Union': African Americans and American Civil Religion," in R. Drew Smith, ed., New Day Begun: African American Churches and Civic Culture in Post-civil Rights America, (Durham, NC: Duke University Press, 2003), 89-1 I2. See also 
and book chapters dealing with the holiday seem more like indictments than like scholarly works. ${ }^{8}$ Overall, there is a tendency of studies on the holiday to condemn political elites' misuse of King's legacy for their own political agendas by selective remembering and/or collective forgetting. ${ }^{9}$

While not denying that political elites have tried to legitimate certain agendas in the name of King (especially the New Right by turning him into a poster boy against affirmative action), ${ }^{\circ}{ }^{\circ}$ this article addresses one of the factors that played a key role, namely civil religion. In doing so, the article examines who (besides the Presidents and the media) shaped the dominant narrative, i.e. the representatives in Congress arguing for the implementation of the holiday as well as Coretta Scott King. King's widow was a central witness to the Congressional hearings and president of the Martin Luther King Center for Non-Violent Social Change (a non-profit organization, hereafter the King Center) and the Martin Luther King, Jr., Federal Holiday Commission (a temporary commission between 1984 and 1996, hereafter the Holiday Commission). ${ }^{11}$

my dissertation, Fly the Flag and Give Thanks to God: Zivilreligion an US-amerikanischen patriotischen Feiertagen, 1945-I992 (Trier: Wissenschaftlicher Verlag Trier, 201 5), 3404I6. On the emergence of two distinct civil religions in the South see Andrew Manis, Southern Civil Religions in Conflict: Civil Rights and the Culture Wars (Macon: Mercer University Press, 2002); Arthur Remillard, Southern Civil Religions: Imagining the Good Society in the Post-Reconstruction Era (Athens: University of Georgia Press, 20I I).

${ }^{8}$ Cf. Scott Hoffman, "Holy Martin: The Overlooked Canonization of Dr. Martin Luther King, Jr.," Religion and American Culture, I0, 2 (2000), I23-48; Michael Dyson, I May Not Get There With You: The True Martin Luther King, Jr. (New York: Touchstone, 2000); Vincent Harding, Martin Luther King: The Inconvenient Hero (Maryknoll, NY: Orbis Books, 2008). For a general overview see William H. Wiggins, O Freedom! AfroAmerican Emancipation Celebrations (Knoxville: University of Tennessee Press, 1987), 134-5 I; Eyal J. Naveh, Crown of Thorn: Political Martyrdom in America from Abraham Lincoln to Martin Luther King (New York: New York University Press, 1990), 177-91; Matthew Dennis, "The Invention of Martin Luther King Jr.'s Birthday," in Amitai Etzioni and Jared Bloom, eds., We Are What We Celebrate: Understanding Holidays and Rituals (New York: New York University Press, 2004), 178-93.

9 Cf. Francesca Poletta, "Legacies and Liabilities of an Insurgent Past: Remembering Martin Luther King, Jr., on the House and Senate Floor," Social Science History, 22, 4 ( 1 998), 4795 I 2; Clayborne Carson, "Reconstructing the King Legacy: Scholars and National Myths," in Peter J. Albert and Ronald Hoffman, eds., We Shall Overcome: Martin Luther King, Jr., and the Black Freedom Struggle (New York: Da Capo Press, 1993), 239-48; Jennifer Selig, "America's Selective Remembering and Collective Forgetting of Martin Luther King, Jr.," Journal of Archetype and Culture, 78 (2007), 219-4I.

10 On how the New Right has distorted the civil right movements' meaning see Jacquelyn Dowd Hall, "The Long Civil Rights Movement and the Political Uses of the Past," Journal of American History, 91, 4 (2005), 1233-63; Denis Bostdorff and Stephen Goldzwig, "History, Collective Memory, and the Appropriation of Martin Luther King, Jr.: Reagan's Rhetorical Legacy," Presidential Studies Quarterly, 35, 4 (2005), 66 I-90.

${ }_{11}$ The majority of the records of the Holiday Commission are housed in the Martin Luther King Jr. Memorial Library in D.C. (hereafter Holiday Commission Records). Already in 


\section{CIVIL RELIGION, THE CIVIL RIGHTS MOVEMENT, AND THE AFRICAN AMERICAN JEREMIAD}

Since Robert N. Bellah's pioneering essay "Civil Religion in America" of I 967 , the concept of civil religion has been widely discussed and criticized. ${ }^{12}$ Yet this article attempts neither to give a comprehensive overview of the extensive literature on the subject nor to solve the debate on civil religion. Rather, it discusses the relation of civil religion to public rituals and minority groups and how it can forge unity but also hamper integration. ${ }^{13}$

Civil religion is an independent religious system with historically evolved symbols "relat[ing] the citizen's role and American society's place in space, time, and history to the conditions of ultimate existence and meaning." ${ }^{14}$ By auguring the United States and its government a divine origin, mission, and protection, civil religion links the nation's history and destiny to the past, present, and future and thereby creates a transcendent and discursive framework. While in theory this transcendence has to be symbolically "open" in order to guarantee consent, the American civil religion is decidedly Judeo-Christian. Thus civil religion is always tied to the specific national background and the nation's history - especially the history of the relationship between church and state (while remaining structurally differentiated from both). ${ }^{\text {is }}$

I 984 Adam Fairclough, "Martin Luther King, Jr. and the War in Vietnam," Phylon, 45, I (1984), 19-39, 20, pointed out that Scott King would not paint a critical and realistic picture of her husband. Moreover, since the 1990 s the King family has been criticized for its "monopoly" on King's legacy and for the commercialization of his name. See Dyson, 250-8I; John Blake, Children of the Movement (Chicago: Lawrence Hill Books, 2004), 55, 95-107.

12 Robert N. Bellah, "Civil Religion in America," Daedalus, 96, I (1967), I-2 1. For an interdisciplinary discussion see Richey and Jones; Phillip E. Hammond, Amanda Porterfield, James G. Moseley, and Jonathan D. Sarna, "Forum: American Civil Religion Revisited," Religion and American Culture, 4, I (1994), I-23; Peter Lüchau, "Toward a Contextualized Concept of Civil Religion," Social Compass, 56, 3 (2009), 37 I-86.

${ }^{13}$ For a historiographical (though partly outdated) overview see James A. Mathisen, "Twenty Years after Bellah: Whatever Happened to American Civil Religion?", Sociological Analysis, 50, 2 (1989), I29-46; Michael Angrosino, "Civil Religion Redux," Anthropological Quarterly, 75, 2 (2002), 239-68.

${ }^{14}$ Gail Gehrig, "The American Civil Religion Debate: A Source for Theory Construction," Journal for the Scientific Study of Religion, 20, I (1981), 5 I-63, 52.

is Civil religion is civil because it plays neither a state nor a church role, though it does not operate completely out of culture. Its symbols are also dependent on the religious life of the nation's most influential denomination(s). However, while denominations can appropriate, represent, or specify civil religious symbols they cannot actively shape these. On the relationship between the church and civil religion see David L. Adams and Ken Schurb, eds., The Anonymous God: The Church Confronts Civil Religion and American Society (St. Louis, MO: Concordia Publishing House, 2004). 
The American civil religion has developed a specific code, creed, and cult, which partially draw on Enlightenment values, the English Puritan heritage, and historically evolved Judeo-Christian symbols, rituals, and moral concepts. Accordingly, it refers to biblical archetypes such as the Chosen People, the Promised Land, sacrifice, and rebirth, while also incorporating events and persons of US history. For instance, the American Revolution is interpreted as the Exodus of Egypt and George Washington as Moses. Moreover, civil religion is "personified" in US institutions creating a civil religious "confession" for the Declaration of Independence, the presidential office, and political ideals such as freedom and democracy. Hence civil religion is a historical (re)construction of US history, "a set of religious beliefs and ultimate values wrapped in, with, and under the political ideals ... In it, national life is apotheosized, national values are religionized, national heroes are divinized, national history is experienced as a Heilsgeschichte, as a redemptive history." ${ }^{6} 6$

As part of the liturgical calendar of the American civil religion, the national holidays express and spread this Heilsgeschichte and in turn, shape "cultural memory": "In this sense, festive culture is part of the general historical process that shapes and transforms power relations, social structures, and popular mentalities." ${ }^{17}$ Hence memory is related to its sponsorship, i.e. the "official memory" of political elites and the "vernacular memory" of ordinary people. While the former seeks to secure the social unity of the "imagined community" by selective remembering or manipulation, the latter can challenge the status quo. ${ }^{18}$

In a similar vein, civil religion can be used by political and/or religious elites as a tool of social cohesion and political legitimation as well as by minority groups and/or grassroots organizations as a critical instrument to voice dissent. Overall, civil religion can serve three functions (though it does not necessarily have to fulfill these): it can legitimate political agendas, integrate citizens, and serve a critical-prophetic function that can be used as a moral backdrop against which the actions and goals of the prevailing interest groups are measured. Civil religion does not necessarily act redemptively, it can also act highly critically as an indictment. Since an overarching integration

${ }^{16}$ Will Herberg, "America's Civil Religion. What It Is and Whence It Comes," in Richey and Jones, $76-88,78$.

17 Jürgen Heideking, "The Constitution, Festive Culture, and America's National Identity," in Roland Hagenbüchle and Josef Raab, eds., Negotiations of America's National Identity: A Series of Interdisciplinary North American Studies (Tübingen: Stauffenburg, 2000), 239-58, 239.

${ }_{18}$ Benedict Anderson, Imagined Communities: Reflections on the Origins and Spread of Nationalism (London: Verso, 1983). On memory see John E. Bodnar, Remaking America: Public Memory, Commemoration, and Patriotism in the Twentieth Century (Princeton, NJ: Princeton University Press, 1992). 
in modern society is highly unlikely (in this case civil religious symbols would have to transcend local, regional, ethnic, religious, gender, age, and class differences), there will never be a civil religion that appeals to everybody. Understood as an overlapping framework, civil religion can evoke social integration but it can also reflect social tensions within a culture. It can legitimate political agendas of various groups but also lead to critical disputes. It can be both a religious implement of the ruling political "class" and a "folk-religious" integrative phenomenon - it can be voiced "from above" and "from below." I9

Bellah identified three "times of trial" that have shaped the American civil religion: the American Revolution and the founding of the republic, the Civil War and the debate on slavery, and the Cold War. All three constitute contexts in which the United States was at war. Additionally, a fourth context needs to be added that highly influenced the development of the American civil religion: the "war" for civil rights. The civil rights movement "reinvigorated the possibility that some moral principles deserved higher loyalty than the established law of the land. It linked a traditional Christian vocabulary of moral righteousness with a liberal political vocabulary of individual right." ${ }^{20}$

As a black Baptist preacher, King viewed his Christian faith as a moral imperative to fight against racism and discrimination. Through nonviolence he sought a color-blind society which would ultimately "redeem the soul of America" (the goal of the Southern Christian Leadership Conference). But King not only played a vital role as a Christian minister, he also became a minister of the American civil religion as he effectively used civil religion in support of blacks' crusade for equality. King addressed both blacks and whites, and viewed himself as God's agent and as the nation's redeemer - a patriotic prophet "willing to suffer courageously for righteousness." ${ }_{21}$ Similarly, he stylized African Americans as "soldiers in the second great American Revolution." 22 By identifying the civil rights movement as a sequel of the American Revolution and as a test for the nation's democratic mission, King enshrined the fight for civil rights in US history. To the same effect, King regularly reminded Americans of the "sacred heritage of our nation," especially the Declaration of Independence (the holy scripture of the

19 Cf. Paul C. Johnson, "Savage Civil Religion," Numen: International Review for the History of Religions, 52, 3 (2005), 289-324; Marcela Cristi, "Durkheim's Political Sociology: Civil Religion, Nationalism and Globalisation," in Annika Hvithamar, Margit Warburg, and Brian A. Jacobsen, eds., Holy Nations and Global Identities: Civil Religion, Nationalism, and Globalisation (Leiden: Brill, 2009), 47-79.

${ }^{20}$ Noll, God and Race, I 42-43.

${ }^{21}$ Martin Luther King Jr., Stride Toward Freedom: The Montgomery Story (New York: Harper, I958), 2 I0.

${ }^{22}$ Martin Luther King Jr., cited in Clayborne Carson, ed., The Autobiography of Martin Luther King, Jr. (New York: IPM, 200I), 257. 
American civil religion) and its historic promise of freedom. ${ }^{23}$ Accordingly, the public intellectual and social critic Cornel West identifies civil religion as one of the four sources of King's ideals (the other three being the black Baptist tradition, liberal Christianity, and Mahatma Gandhi's teachings). ${ }^{24}$ By linking biblical themes and metaphors of divine salvation and liberation to US history and political ideals, King used the Judeo-Christian vocabulary of civil religion and its prophetic function both to rally support and to question the notion of the chosen nation.

This notion of the chosen nation is central not only to the American civil religion but also to the African American jeremiad and its conception of "a chosen people within a chosen people." ${ }_{25}$ King skillfully linked the American civil religion to the African American jeremiad that had emerged in the nineteenth century as a "rhetoric of social criticism and prophecy." ${ }_{26}$ The African American jeremiad is structurally and textually similar to the classical American jeremiad as both express a millennial faith in America's promise. Yet the former is more radical in its social criticism and in demanding social reform: after reminding the nation of its promise of freedom, it criticizes the present retrogression from that promise. However, in the end, the jeremiad reassures society that it will eventually complete its mission and redeem that promise. ${ }^{27}$

The most famous example of the African American jeremiad is King's "I Have a Dream" speech. Like a civil religious sermon in front of the Lincoln Memorial, King articulated his dream, which was "deeply rooted in the American dream" - a dream of a nation united through justice and brotherly love. He linked the ideals of Christianity with the inalienable rights of every citizen and reminded the nation of the "promissory note" and "sacred obligation" in the American Constitution, the Declaration of Independence, and the Emancipation Proclamation. Now was the time for that promise to be fulfilled, "to make justice a reality for all of God's children." ${ }^{28}$ By appealing to scriptural and patriotic authorities, King invoked civil religion and followed the traditional pattern of African American jeremiads: past promises had only led to current failure but eventually would be fulfilled. This argument by trajectory

${ }^{23}$ Martin Luther King Jr., I 6 Jan. I 963 , "Letter from Birmingham Jail.” See also King, 5 Dec. 1955, "Address to the First Montgomery Improvement Association Mass Meeting."

${ }^{24}$ Cornel West, "The Religious Foundations of the Thought of Martin Luther King, Jr.," in Albert and Hoffman, eds., We Shall Overcome, I 13 -29, I 27-28; Christa Buschendorf, "'We Need Martin More Than Ever': Interview with Cornel West on Martin Luther King, Jr., August 201 I," American Studies, 56, 3 (201 I), 449-67, 455.

${ }^{25}$ Howard-Pitney, The African-American Jeremiad, I 53. ${ }^{26}$ Ibid., 3 .

${ }^{27}$ Ibid., 7, I49; Sacvan Bercovitch, The American Jeremiad (Madison: The University of Wisconsin Press, 1978).

${ }^{28}$ Martin Luther King Jr., 28 Aug. 1963, "I Have a Dream." 
empowered King to define himself as a stakeholder in a principle - the US would inevitably achieve full democracy for all at some future moment.

However, as King extended his campaign after 1965, fighting against high unemployment rates of blacks in Los Angeles, for fair housing in Chicago, and in support of striking black sanitation workers in Memphis, his dream turned into a "nightmare." ${ }^{29}$ King explicitly linked racism to economics and called for a strong federal government to counteract the historical disparities between blacks and whites. In identifying the "triple evils" (the link between racism and poverty at home and militarism abroad), a revolution of values was no longer enough; actual political steps needed to be taken. ${ }^{30}$

Meanwhile, King did not break with civil religion or the jeremiad - his hope and optimism were still deeply rooted in his belief in God and in the political legacy of the United States: "The racism of today is real, but the democratic spirit that has always faced it is equally real ... A people who began a national life inspired by a vision of society of brotherhood can redeem itself." ${ }^{3}$ ' Yet the nation still had a long way to go to reach "the promised land of freedom." The revolution was not over; "we still need some Paul Revere of conscience to alert every hamlet and every village of America that revolution is still at hand." ${ }_{2}$

Ultimately, King evolved as an interpreter of a highly critical, African American civil religion influenced by the African American jeremiad. $\mathrm{He}$ knew the power of this symbolism, which spoke to both black and white audiences. ${ }^{33}$ And yet he might have also been aware of the pitfalls of such rhetoric, especially of his earlier, more uplifting oratory. As historian Jacquelyn Dowd Hall notes, it is these endlessly reproduced and selectively quoted speeches that "retain their majesty yet lose their political bite." ${ }_{44}$ While effectively appealing to a broad audience and forging a sense of unity, civil religion can also mask "real" progress and lead to a merely symbolic "pseudo-integration."

Hence it is not surprising that political elites used this kind of civil religious symbolism. Two and a half months prior to King's famous "I Have a Dream"

${ }^{29}$ Martin Luther King Jr., 24 Dec. 1967, “A Christmas Sermon on Peace.”

30 Cf. David J. Garrow, Bearing the Cross: Martin Luther King, Jr., and the Southern Christian Leadership Conference (New York: W. Morrow, 1986), 527-74; Martin Luther King Jr., 22 May 1967, "Remarks at a SCLC Staff Retreat"; King, 4 April 1967, "Beyond Vietnam."

${ }^{31}$ Martin Luther King Jr., Where Do We Go From Here: Chaos or Community? (New York: Harper \& Row, 1967), 83. See also King, 3 I March 1968, "Remaining Awake through a Great Revolution"; Howard-Pitney, The African-American Jeremiad ..., $214-16$.

${ }^{32}$ Martin Luther King Jr., I6 Aug. 1967, "Where Do We Go From Here." In public memory Revere is known for alerting the colonial militia before the battles of Lexington and Concord during the American Revolution.

33 On the effect of King's rhetoric see also Keith Miller, "Epistemology of a Drum Major: Martin Luther King, Jr. and the Black Folk Pulpit," Rhetoric Society Quarterly, 18, 3-4 (1988), 225-36.

${ }^{34}$ Dowd Hall, "The Long Civil Rights Movement," I 234. 
speech, President John F. Kennedy declared civil rights a moral issue, "as old as the Scriptures and ... as clear as the American Constitution." 35 Similarly, President Lyndon B. Johnson viewed the Civil Rights Bill of 1964 and the Voting Rights Act of 1965 as inevitable steps "to forge an ideal of freedom" in the history of the nation, as a test the nation was not allowed to fail. ${ }^{36}$

Eventually, the implementation of a holiday in King's honor turned out to be that test that was supposedly "passed" in 1983 when the day was officially recognized. After all, the holiday, as Coretta Scott King had already asserted during the Congressional hearings in I979, was "the most important affirmative of this Nation's willingness to live out the meaning of its creed." 37 And this suggested that the nation was not only living out the meaning of its creed, but had in fact kept its promise. Apparently there was no need for further action.

\section{THE MARTIN LUTHER KING HOLIDAY: A CONTESTED COLLECTIVE MEMORY}

It took fifteen years in Congress, over eighty legislative drafts, and three hearings in subcommittees (in 1975, 1979, and 1983) ${ }^{38}$ before Martin Luther King's birthday was officially declared a national holiday in 1983.39 The

35 John F. Kennedy, i June 1963, "Radio and Television Report to the American People on Civil Rights," APP.

${ }^{36}$ Lyndon B. Johnson, 2 July 1964, "Radio and Television Remarks upon Signing the Civil Rights Bill," APP; Johnson, 6 Aug. 1965, "Remarks in the Capitol Rotunda at the Signing of the Voting Rights Act," APP.

37 Coretta Scott King, cited in US Congress, Senate, Committee on the Judiciary and House Committee on Post Office and Civil Service, Joint Hearings: Martin Luther King, Jr., Holiday (Washington, DC, 1979), 24. See also N.N., "The Essence of the Holiday: Tributes and Wisdom," in Holiday Commission, Ig86 Report I (Washington, DC: The Commission, 1986), 6-9.

${ }^{38}$ US Congress, House, Subcommittee on Census and Population of the Committee on Post Office and Civil Service, 'Hearing: A Bill to Designate the Birthday of Martin Luther King, Jr., as a Legal Public Holiday' (94th Cong., H.R. I 8 ıо, ı o. Sept. 1975, Washington, DC); US Congress, Senate, Committee on the Judiciary and House Committee on Post Office and Civil Service, 'Joint Hearings: Martin Luther King, Jr., Holiday' (96th Cong., S. 25, 27 March-2I June 1979, Washington, DC); US Congress, House, Subcommittee on Census and Population of the Committee on Post Office and Civil Service. 'Hearing: Martin Luther King, Jr., Holiday Bill' (98th Cong., H.R. 800, 7 June 1983, Washington, DC).

39 Public Law 98-1 44 (97 Stat. 917, 2 Nov. 1983). See also "Martin Luther King Birthday," I 3 Nov. 1979, in Congressional Record - House, Volume CXXV (Washington, DC: GOP), 32136-44; "Designation of the Birthday of Martin Luther King, Jr., as a Legal Public Holiday," 2 Aug. 1983, in Congressional Record - House, Volume CXXIX (Washington, DC: GOP, 1983), 22208-43; "Martin Luther King, Jr. Holiday" (3 Oct. 1983), in Congressional Record - Senate, Volume CXXIX (Washington, DC: GOP 1983), 26866- 
first attempt was made only four days after King's death in 1968 by Congressman John Conyers (D-MI), who played a decisive role in the implementation of the holiday during the Congressional debates, which will be dealt with in the next section..$^{\circ}$

Moreover, Coretta Scott King probably shaped the holiday more than any other person and can be described as the architect of the holiday. Her contribution, as Scott King explained in 1983, was "to ensure that Martin would be properly memorialized." 41 And in the process of ensuring a "proper" memorialization in the I970s and I980s the King Center, the Holiday Commission, Congressmen, Presidents, and the media formed and spread a civil religious interpretation of King that until today has had a lasting impact on his legacy.

\section{THE CONGRESSIONAL DEBATE: AN “APOSTLE OF NONVIOLENCE"}

During the Congressional debates and hearings between 1975 and 1983 the opponents to the holiday brought forth economic as well as moral arguments. On the one hand, they contended that the holiday was just an excuse for another day off for employees that was too expensive for the federal budget. ${ }^{22}$ On the other hand, they strategically tried to dismantle the worth of King on three levels: first, they argued that a holiday in honor of one person was a break with tradition (with the exception of George Washington and Christopher Columbus). Only a "test of time" could tell whether King deserved a holiday. Second, even if King's contributions were eventually recognized, he was only a hero for a small segment of society, hence there was no need for a national holiday. ${ }^{43}$ Third, King was neither a hero to African Americans nor to Americans in general, let alone a patriot.

87; "Martin Luther King, Jr., Holiday," 19 Oct. 1983, in Congressional Record - Senate, Volume CXXIX (Washington, DC: GOP, I983), 2834I-8 I.

${ }^{40}$ Cf. H.R. I65 10, 80 th Cong., 8 April 1968. Except for the drafts by Edward W. Brooke (R$\mathrm{MA}$ ) and Laurence J. Burton (R-UT) all drafts were handed in by Democrats. Among others, other important actors/groups were the Southern Christian Leadership Conference, the National Association for the Advancement of Colored People, and the Congressional Black Caucus.

${ }^{41}$ Coretta Scott King, cited in the March on Washington Newsletter, Aug. 1983, I, I, in Holiday Commission Records, Box 5. See also Scott King, "Chairperson's Summary Statement," 8 Dec. 1986, in ibid., Box 4; Scott King, "Remarks," 5 Nov. 1990, in Holiday Commission, Iggr Annual Report (Washington, DC: The Commission, I991), 77-79.

${ }^{42}$ Cf. Cong. Record I25 (i 3 Nov. 1979), 32 136-39; Cong. Record 129 (2 Aug. 1983), 22209-1 I, 22228, 22233; Cong. Record I29 (3 Oct. I983), 26865-67. On the Congressional debates see also Wiggins, $O$ Freedom!, I 34-5 I.

${ }^{43}$ Cf. Cong., Hearings (1979), 84; Cong. Record I29 (3 Oct. I983), 2688 I-82. 
People had been misled, King was in fact a subversive, a communist sympathizer. ${ }^{44}$ Jesse Helms (R-NC) was the most vocal on this issue: King was "a source of tension, a deeply troubling symbol of a divided society." 45

In response, the supporters of a King holiday maintained that a cost-benefit analysis was obsolete when assessing the historical value of King. ${ }^{46}$ Additionally, they cloaked their arguments in civil religious symbolism by building on King's self-image. In three steps the proponents painted a decidedly civil religious image of King, stylizing him as a prophet, an "American saint, American patriot, American black, American humanitarian; a man all Americans can be proud of; a man all the world knows as the essence of what is best about America." 47

First, the supporters insisted that King was no communist but a democratic pioneer whose ideals were deeply rooted in the nation's Judeo-Christian heritage. Since King had regularly evoked Jefferson, Lincoln, the Declaration of Independence, and the Constitution in his speeches, he was a patriot and his dream the American dream. ${ }^{4}$ In turn, King should indeed be compared to Washington and Lincoln as the civil rights movement ranked similar to the American Revolution and the Civil War. Like her husband in his lifetime, Scott King in her testimony before Congress called the civil rights movement the "Second Revolution," another episode in the "holy" history of the nation. ${ }^{49}$ Similarly, Rev. Joseph E. Lowery explained, King's leadership

demonstrated the unity in diversity that portends a greatness unparalleled in nationhood - under God. If Columbus discovered America, Martin helped America discover itself. If Washington established a Nation, Martin led the Nation to understand that there can be no nationhood without brotherhood. ${ }^{50}$

Thus the holiday in King's honor was another milestone for a nation "under God."

${ }^{44}$ Cf. Cong., Hearing (1975), 9; Cong., Hearings (1 979), 3, 34, 42-5 1, 65, 73-77, 84, 90; Cong. Record I25 (1 3 Nov. 1979), 32 1 37-40; Cong. Record I29 (2 Aug. 1983), 22239; Cong. Record 129 (3 Oct. 1983), 26865, 26868.

45 Jesse Helms, cited in Cong. Record I29 (3 Oct. 1983), 26868. See also Helms, The King Holiday and Its Meaning (St. Louis, MO: Council of Conservative Citizens, 1998).

${ }^{46}$ Cf. Cong. Record 125 (I 3 Nov. I 979), 32 I 4 I-42; Cong. Record 129 (2 Aug. I983), 222 I 0 - I I, $22217,22228,22230,22235$.

47 Marc Stepp (United Auto Workers), cited in Cong., Hearing (1975), I 5 . See also Cong., Hearing (1983), 30; Cong. Record 129 (2 Aug. 1983), 22212-18; Cong. Record I29 (3 Oct. 1983), 26870.

${ }^{48}$ Cf. Cong., Hearing (1975), I o; Cong., Hearings (1 979), 48-49; Cong. Record I25 ( 13 Nov. 1979), 32143; Cong., Hearing (1983), 28; Cong. Record 129 (2 Aug. 1983), 22212-13, 22216-17, 22229-30, 22235, 22242; Cong. Record I29 (19 Oct. 1983), 28364, 28373.

49 Coretta Scott King, cited in Cong., Hearing (1983), 9.

so Joseph E. Lowery, cited in Cong., Hearings (1979), 27-28. See also Cong. Record I29 (I 9 Oct. 1983), 28360; Cong., Hearing (1983), 23-24; Cong. Record 129 (2 Aug. 1983), $22210,22214,22232-34,22238$. 
Second and third, the civil religious themes of sacrifice and rebirth were linked to King's fight for civil rights. Edward Kennedy (D-MA) exclaimed in 1983 that King

dedicated his life - and then gave his life - to complete the unfinished business of the American Revolution and the Civil War ... In a very real sense, he was the second father our country, the second founder of a new world that is not only a place ... but a noble idea, a set of ideals. ${ }^{51}$

As King had given his life for the nation he had initiated a rebirth of the nation. After all, King was an "apostle of nonviolence" and a "hair shirt for the nation's conscience." $52 \mathrm{He}$ had changed the "hearts" and "minds," as John Conyers declared.53 The ideals of the American Revolution and the Civil War were finally achieved. Thus the holiday was a symbol of King's sacrifice for democracy, of forgiveness, reconciliation, and redemption. The holiday stood for all Americans. ${ }^{54}$

By painting a decidedly civil religious image of King the advocates of his holiday made a convincing plea for its implementation. 55 Already in 1979 Republican representative John M. Ashbrook $(\mathrm{OH})$, an opponent to the holiday, criticized the fact that King was canonized by his supporters and the media. ${ }^{56}$ And this canonization was further propelled by Coretta Scott King and the elaborate public relations campaign of the King Center and the Holiday Commission.

\section{KEEPERS OF THE DREAM: THE KING CENTER AND THE HOLIDAY COMMISSION}

The King Center was founded in 1968 as a "living memorial" in honor of King, "a physical, spiritual, and educational mecca for nonviolent activists from all over the world." 57 Together with the Ebenezer Baptist Church it became a National Historical Site in 1980 and today is one of the most

${ }^{51}$ Edward Kennedy, cited in Cong. Record 129 (19 Oct. 1983), 28367.

52 Edward Kennedy, cited in Cong., Hearing (1983), 19; Jim Wright (D-TX), cited in Cong., Hearing 1 983, 4. See also Cong., Hearings (1979), 9; Cong. Record I29 (2 Aug. 1983), 22208, 222 14-16, 22230-3 I, 22234. 53 John Conyers, cited in Cong., Hearing (1983), 42.

54 Cf. Cong., Hearing (1 975), I 2, 22-23; Cong., Hearings ( 1979), I 4, 16, 25; Cong. Record I29 (2 Aug. 1983), 22210, 22213, 22216, 22229-36, 22241.

s5 By the early 1980s, the arguments against the holiday no longer played a key role in the national media. See William Starosta, "A National Holiday for Dr. King? Qualitative Content Analysis of Arguments Carried in the Washington Post and New York Times," Journal of Black Studies, i 8, 3 (1988), 358-78.

${ }_{56}$ John M. Ashbrook, cited in Cong., Hearings (1 979), 90. See also Cong., Hearing (1983), 79.

57 See www.thekingcenter.org/about-king-center; Coretta Scott King, "President's Message," in King Center, Annual Report I98I (Atlanta, GA: King Center, I98I), 3. 
popular historic attractions in the US. Until the Holiday Commission was established in 1984 the center headed the drive for a King holiday and set the standards for honoring King. As early as 1969 it organized a "King Week" in Atlanta. ${ }^{8}$

After the official implementation of the Martin Luther King Holiday in 1983, the Holiday Commission was established to provide advice and assistance in promoting and coordinating the new holiday. It was composed of four officers from the executive branch and four Senators, all eight appointed by the President; four members of the House of Representatives, appointed by the Speaker; Coretta Scott King and two other King family members; two representatives of the King Center; and fourteen individuals representing such diverse groups as labor, business, and entertainment. 59

Scott King described the commission's work and mission as addressing "in the most fundamental details the American dream and the American experience. Its mission speaks to the moral leadership of a Washington, Jefferson, Madison, and Lincoln; its work speaks to the blessings of our constitutional system." 60 Just like during the Congressional debates and hearings, Scott King linked her husband's fight for freedom to the nation's history and thereby created a sense of continuance.

The commission's official logo cited its motto, "Living the Dream," and showed King and the American flag - the "badge of America's political faith." ${ }_{1}$ The commission annually submitted reports to Congress and the President and issued a monthly newsletter called Living the Dream. As its president, Scott King held an annual "State of the Dream" address in allusion to the presidential "State of the Union" address. Moreover, various

${ }^{8} 8$ After the dissolution of the Holiday Commission in 1996 the King Center again took over. In the year 2000 The King Center's National Holiday Advisory Committee was established. On the King Center see N.N., "Prologue and Dedication," in Holiday Commission, 1986 Report I, 2-3; "Making of the King Holiday: A Chronology," at www.thekingcenter.org/ making-king-holiday.

59 Cf. Public Law 98-399 (98 Stat. 1473, 27 Aug. 1984, H.R. 5890), Section 2, 4.

60 Coretta Scott King, "Transmittal Message," in Holiday Commission, 1989 Annual Report (Washington, DC: The Commission, 1989), 5. See also Scott King, "The Making of a Holiday and Beyond" (I5 April 1986), in Holiday Commission, I986 Report II (Washington, DC: The Commission, I986), n.p.; N.N., "Reflections on the King Legacy," in Holiday Commission, 1988 Annual Report (Washington, DC: The Commission, 1988), 9 .

${ }^{61}$ James A. Moss, The Flag of the United States: Its History and Symbolism (Washington, DC: United States Flag Association, I94I), 85. Cf. N.N., "Institutionalizing the Holiday," in Holiday Commission, 1988 Annual Report, 6-8. The full motto reads as follows: "Living the Dream - Let Freedom Ring for Universal Peace with Justice, Human Rights, Social and Economic Progress for All Peoples through Kingian Nonviolence." Holiday Commission, I989 Annual Report, 8-9. 
committees were created that were responsible for certain areas such as education or legal advice. Eventually the commission operated within a large network of over seven hundred organizations. ${ }^{62}$

Its public relations committee produced various advertising materials, such as the "Living the Dream Pledge Card," "The Martin Luther King, Jr. Official Holiday Seal" and the "Freedom Trail Poster" - all of which portrayed King as a prophet and redeemer and echoed the civil religious message that the holiday stood for the nation's "sacred" history. ${ }^{63}$ For example, the poster displayed key moments of King's life and the civil rights movement and announced the national and local highlights of events. The background showed the Liberty Bell, which symbolically stands for America's independence. In 1987 over 70,000 and in 1988 over 100,000 posters were distributed serving a teaching and remembering function, "as a catalyst for creating the feeling of togetherness and oneness of spirit." 64

Overall, the commission saw itself as the keeper of King's legacy, setting the holiday's standards and guidelines. Its September 1987 newsletter explained the significance of the holiday as follows:

As a nation chooses its heroes and heroines, it interprets its history and shapes its destiny. The annual observance of the national holiday in honor of Dr. Martin Luther King, Jr., if observed appropriately, can help America realize its true destiny as the global model for democracy, economic and social justice. Let Freedom Ring! ${ }^{65}$

And honoring King "appropriately" (however elusive and flexible that term might be) meant following three guiding principals: "remember, celebrate

${ }^{62}$ Cf. Public Law 98-399, Section 8; "Educational Materials for Observing Martin Luther King, Jr. Day January i 5 th" (1979), in Holiday Commission Records, Box 5; N.N., "Commission Highlights," in Holiday Commission, 1986 Report I, 42-43; Coretta Scott King, "The State of the Dream," is Jan. 1989, in Holiday Commission, I989 Annual Report, 4I-47; N.N., "National Committee Activities," in Holiday Commission, IggI Annual Report (Washington, DC: The Commission, 199I), 4I-59.

${ }_{63}$ Cf. "Freedom Trail," in Holiday Commission Records, Box 2; "Minutes. Regular Meeting of the Martin Luther King, Jr. Federal Holiday Commission and the Martin Luther King, Jr. Federal Holiday Corporation," 27 May 1987, in ibid.; "Summary of Marketing Plan for Federal Holiday Commission Hand Bell," in ibid., Box 5; N.N., "A Holiday for All America: To Redeem the Soul of the South," in Holiday Commission, Ig86 Report I, 32-34; N.N., "The Challenge of the Dream", in ibid., 30-31; Coretta Scott King, "Remarks," 5 Nov. 1990, in Holiday Commission, I99I Annual Report, 77-79.

64 "Join the Freedom Trail: Criteria and Guide," in Holiday Commission Records, Box I. See also "Promoting, Marketing and Cost of Freedom Trail, for Federal Holiday Commissioners Only," in ibid.; "Living the Dream," May 1988, in ibid., Box 5; N.N., "Institutionalizing the Holiday," in Holiday Commission, I988 Annual Report, 6-8.

${ }^{65}$ Living the Dream, Sept. 1987, in Holiday Commission Records, Box 2. See also N.N., "Prologue and Dedication," in Holiday Commission, 1986 Report I, 2-3; Scott King, "How We Can Observe This Holiday," Washington Post, 23 Oct. 1983, C8. 
and most importantly act to continue King's unfinished work in building the 'beloved community'." 66

The holiday was meant to be racially, ethnically, and culturally inclusive - a day of hope and renewal, a day of reflection, but also of inspiration and of political activism. ${ }^{67}$ Accordingly, the underlying theme of the 1986 celebrations in DC was "Peace and Justice in Central America and South Africa." Similarly, in 1988 the commission started its Heritage Action Project supporting housing development in underdeveloped districts. ${ }^{68}$ Regularly, the commission called on the American people - as King "s "disciples" and the "keepers" of his legacy - to "rededicate," to "reaffirm," to "recommit" to his dream. ${ }^{69}$ However, this call for activism at times got lost behind the day's civil religious symbolism.

\section{REMEMBERING A PROPHET, CELEBRATING UNITY, AND FORGETTING ACTIVISM?}

As Presidents and the media picked up the call for activism, $7^{\circ}$ they also picked up the civil religious interpretation of King, which enhanced the feeling of unity but also contradicted the actual appeal. First, the picture of King as a

${ }^{66}$ N.N., "The Making of the King Holiday," in Holiday Commission, Report 1993 (Washington, DC: The Commission, I993), I $83-85$, I 83.

${ }^{67}$ Cf. Coretta Scott King, "Formal Statement: Opening of Washington Offices," 25 March 1985, in Holiday Commission Records, Box 4; "Martin Luther King Fact Sheet," in ibid., Box I; N.N., "Celebrating the Holiday," in Holiday Commission, Ig86 Report I, 24-25; Coretta Scott King, "Foreword," in Holiday Commission, I988 Annual Report, 2; N.N., "Prologue," in Holiday Commission, Iggo Annual Report, 6-7; N.N., "Commission Services to the Public," in Holiday Commission, I9gI Annual Report, 68-69.

${ }^{68}$ Cf. "Minutes of the D.C. Martin Luther King, Jr., Holiday Commission," г Dec. 1986, in Holiday Commission Records, Box 2; N.N., "Institutionalizing the Holiday," in Holiday Commission, 1988 Annual Report, 6-8; N.N., "Attachment A: 1988-89 Proposed Work Plan," in ibid., 44-53.

${ }^{69}$ Cf. "Martin Luther King Fact Sheet," in Holiday Commission Records, Box I; "Living the Dream: Our National Holiday. January 20, 1986," in ibid.; Coretta Scott King, "Martin Luther King, Jr. Federal Commission Meeting: Opening Remarks," 7 March 1988, in ibid., Box 3; Scott King, "The State of the Dream," I 5 Jan. 1988, in ibid.

${ }^{70}$ Cf. Gerald Ford, I 4 Jan. 1975, "27 - Remarks on the Anniversary of the Birth of Martin Luther King, Jr.," APP; Ronald Reagan, I4 Jan. 1986, "Message on the Observance of Martin Luther King, Jr. Day," APP; George W. Bush, I7 March 1989, "Remarks on Signing the Martin Luther King, Jr., Federal Holiday Commission Extension Act," APP. See also Lena Williams, "Most of U.S. Will Honor Dr. King, but Some Still Dispute the Holiday," New York Times, I 8 Jan. 1987, I, 24; Sebastian Rotella, "Around the South Bay: Martin Luther King's Dream Is Thriving at Inglewood High School," Los Angeles Times, I5 Jan. 1989, Part II, 5-6; Peter Appelbome, "A Nation Tries to Decide How to Recall Martin Luther King," New York Times, I 4 Jan. 1990, E4; Christine Spolar, "A Time to Renew Ideals of 'Prince of Peace'," Washington Post, 22 Jan. I991, Ci, C6. 
prophet, as "the Moses of our people," was regularly invoked in newspaper articles and presidential addresses. ${ }^{71}$ In his 1983 radio address, President Reagan reminded the nation to thank God for sending men like King, to be grateful "for the providence that sends among us men and women with the courage and vision to stand peacefully but unyieldingly for what is right.". 72 In the following years, Coretta Scott King frequently reiterated these exact same words in her public speeches and media pieces. ${ }^{73}$

Second, this image was linked to the civil religious theme of sacrifice. Since his death numerous articles granted King the status of a martyr: he had fought and died in a holy mission for the American democratic principles. ${ }^{74}$ King's faith, his divine mission, and the circumstances of his death led to the conclusion that he had sacrificed himself for the nation. In turn, his legacy was ascribed a higher, transcendent goal, as a student from DC explained in a letter to the editor in the Washington Post in 1986: "King's holiday will be a meaningful day for me, a day for me to be thankful that King gave his life so mine could be brighter." 75

Third, King was frequently compared to Washington and Lincoln and the civil rights movement was embedded in the nation's history. In 1983 an article in the Los Angeles Times proclaimed,

Call it a national holiday, for that is the legal term, but it will be more: a solemn celebration of a turning point in the history of the American nation, a time to remember not only Martin Luther King Jr., whose name the day will bear, but all that he

${ }^{71}$ Milloy Courtland, "At a Seedy Motel in Memphis, a Dream Goes Unrealized," Washington Post, 2 I Jan. I986, AI, A6. See also Bob Dole, "The Legacy of the "Unreasonable' Man," Washington Post, 23 Oct. 1983, C8; Ronald Reagan, I6 Jan. 1986, "Message to the Congress of Racial Equality on the Observance of Martin Luther King, Jr. Day," APP; George Bush, 9 Jan. I990, "Remarks on Signing the Martin Luther King, Jr., Federal Holiday Proclamation," APP.

${ }^{72}$ Ronald Reagan, I 5 Jan. 1983 , "Radio Address to the Nation on the Anniversary of the Birth of Martin Luther King, Jr.," APP.

${ }^{73}$ Cf. "To Our Friends and Supporters," Nov. 1978, in Holiday Commission Records, Box 5; Scott King, "Opening of Washington Offices"; Scott King, "The State of the Dream," I 5 Jan. 1989, in Holiday Commission, I989 Annual Report, 4I-47, 46.

74 Cf. Herbert Mitgang, "The Race Crisis: A Non-violent Man Is Martyred," New York Times, 7 April I968, Eı; N.N., “A Day for Martin Luther King," New York Times, I I Oct. I983, A30; David Treadwell, "Day of Tributes across Nation Honors King," Los Angeles Times, 2 I Jan. I 986, OC I, I 6; Leah Y. Latimer and Sue A. Pressley, "Observances Vary on a Young Holiday: King's Dream a Goal for Many," Washington Post, 20 Jan. I987, AI, A4; Jacqueline Trescott, "Sharing King's Dream: Bush Pledges to Work for Racial Equality," Washington Post, I 7 Jan. 1989, B3.

75 Jerome K. Battle, "King's Legacy - King's Day: How Some Will Spend It. 'I Will Reflect'," Washington Post, I9 Jan. 1986, G8. See also Eric Pianin and Caryle Murphy, "Martin Luther King Day Observed with Parade, Library Speeches," Washington Post, 17 Jan. I984, AI, B4; Renate Robey, "Older Generations Pass on the Legacy and the Dream," Los Angeles Times, 2 I Jan. 1986, V_A6. 
symbolized in a nation that had somehow forgotten the way charted by its founders ... So, on the third Monday of each January, will a grateful America give thanks for its diversity, rededicated justice, justice for all, and reinspired by the hope of a black preacher's dream. "Free at last." 76

King had led the battle for freedom began by the Pilgrims, which ended in a "second Reconstruction" - regardless of the fact that the first Reconstruction had failed. ${ }^{77}$ The goals of the American Revolution and Civil War seemed to be achieved. Therefore King's death symbolized the renewal of "the American experiment"; the nation had returned to the "right" path. The promise of the Declaration of Independence seemed to be fulfilled: "King changed us. King opened our hearts ... Because of him we are a better people." 78

This argument was further strengthened by the annual presidential speeches and proclamations on his birthday that followed a similar pattern: while the conflict over equal rights originated in a renunciation of American ideals, it had now been overcome through a return to these ideals. King had facilitated such recollection because, as President Jimmy Carter explained in I 979, he had never stopped believing in the "promise of our democracy." 79

The civil rights movement was stylized as an era of "national rebirth" and King turned into the "Apostle of Reconciliation" - between the races, the rich and poor, and for a society shattered by the Vietnam War. ${ }^{\circ \circ}$ This conveyed a sense of full integration: after a long struggle the African American community had finally been integrated into US society through rebirth, salvation, and renewal.

${ }^{76}$ N.N., "A Great Day," Los Angeles Times, 5 Oct. 1983, C6. See also N.N., "The King Holiday," Washington Post, 20 Jan. 1986, Aı 8; Mark Ridley-Thomas, "A Day to Celebrate by Expanding the New American Revolution," Los Angeles Times, 20 Jan. I $986, \mathrm{~B} 5$.

77 Cf. Vernon E. Jordan Jr., "is Years Later: Black and White. Where the Civil Rights Revolution Is Now," Washington Post, 3 April 1983, D8.

${ }^{78}$ Jonathan Yardley, "How King Changed Our Lives," Washington Post, 20 Jan. 1986, C2. See also Martin Arnold, "Dr. King Honored Quietly Over U.S. 4ist Anniversary of Birth Is Observed in Religious Services and Speeches," New York Times, I6 Jan. 1970, I, 16; N. N., "How to Remember Martin Luther King," New York Times, Io Dec. 1982, A34; Richard C. Paddock, "King Changed U.S. Course, Governor Says," Los Angeles Times, I9 Jan. 1986, OC_A20.

79 Jimmy Carter, I 3 Jan. 1979, "Remarks Accepting the Martin Luther King, Jr. Nonviolent Peace Prize," APP.

8० Charles McCurdy Mathias, "Martin Luther King: Apostle of Reconciliation. His Memory Reminds Us That the Enemies of Today Are the Allies of Tomorrow," Washington Post, 2 I Jan. I991, A2 I. See also N.N., "Martin Luther King Day," Washington Post, I 5 Jan. I 985 , Ar 6; Williams, "Most of U.S. Will Honor Dr. King"; Jean Davidson and George B. Smith, "King Day Celebrated with Pride, Hope," Los Angeles Times, I7 Jan. I989, Part II, I, 7; Peter Appelbome, "King Holiday Observances Point Out Both Pain and Triumphs," New York Times, 16 Jan. I990, A. 
The Martin Luther King Day, as sociologist Adam Gamoran argues in his article on civil religion in American schools, shows

the potential of civil religion to provide unity in a diverse society; for it reflects the hopes and gains of a subgroup that has been alienated from many of the traditional civil religious themes ... Acceptance of King's birthday thus enhances the integrative work of American civil religion. ${ }^{81}$

However, what Gamoran overlooks is that by turning King into a civil religious icon and remembering him as a prophet who initiated and successfully ended the nation's renewal, the call for further political activism is rendered obsolete. While civil religious symbolism has helped the civil rights movement and the establishment of King's holiday, it has also hampered factual integration of African Americans. As Paul Goetsch points out, civil religion can mask

the absence of a sober economic and sociological analysis of the difficulties of people of color ... The rational discussion of the proposed political measures is substituted by assertions that are in keeping with American values. Moreover, an optimism is expressed that momentarily distracts the audience from the actual situation. ${ }^{82}$

In the process of portraying King as the nation's savior and thereby stylizing him as a civil religious symbol of integration and of nonviolent social change, the general public was "distracted" confusing symbolic with real progress. Hence it is not surprising that this image of King has been successfully used in the fight against affirmative action since the r 980 os.

\section{CONCLUSION: "WE DID NOT INTEND TO CELEBRATE AN END TO THE STRUGGLE"}

During the course of the I970s and I980s, King and the civil rights era were integrated into the sacred tale of US history. Similar to Washington and Lincoln, King entered the pantheon of America's (civil religious) heroes. Stylized as a saint and a prophet who had delivered the American people, King became the first decidedly African American symbol in the American civil religion. Thus, on the one hand the day relates to already established African American holidays such as the Emancipation Days in honor of the abolition of slavery. On the other hand, the day is closely tied to already

${ }^{81}$ Adam Gamoran, "Civil Religion in American Schools," Sociological Analysis, 5 I, 3 (1990), 235-56, 253.

82 Paul Goetsch, "In the Bully Pulpit: Presidential Rhetoric between Sermonizing and Agenda Setting," in Hagenbüchle and Raab, Negotiations of America's National Identity, 330-46, 343 . 
established traditional holidays like Independence Day as it celebrates unity in the democratic "spirit of ' 76. ." 83

But already in the first year of the holiday's official nationwide celebration in 1986 Coretta Scott King wistfully reminisced,

We did not intend to celebrate an end to the struggle of justice, freedom, and peace, any more than the celebration of George Washington's Birthday means that our new and young nation is already God's Kingdom on earth. It was never our intent to allow Martin to be seen only as a dreamer whose dream was now fulfilled. This is why we and the Federal Commission insisted that the Holiday celebrations be both commemorative as well as substantive. ${ }^{84}$

The day was not meant to celebrate an end to the struggle. However, the holiday's dominant civil religious interpretation of redemption deemed any analysis of systematic problems irrelevant and it revealed the inherent contradiction of the three elements "remember, celebrate, and act." While the unifying and legitimizing power of civil religion had helped to establish the holiday, its sponsors did not reckon with civil religion's pitfalls. Dead men can indeed "make such convenient heroes."

King could easily be incorporated into the American civil religion because he himself had used these themes, standing in the long tradition of the African American jeremiad. But remembering a prophet who had changed the United States, and celebrating this newly found unity and reconciliation between the races, suggested that everything was achieved. The Heilsgeschichte seemed to be finished. And Presidents as the "high priests" of the American civil religion were successful in elevating their political agendas via civil religious rhetoric to universal truths. ${ }^{85}$

Since the Reagan administration civil rights legislation has virtually come to a halt, and since the mid-I990s King's "I Have a Dream" speech has been mentioned either on his holiday or in political propaganda adverts against affirmative-action programs. ${ }^{86}$ For the majority of Americans, quotas are regarded as an illegal preference: 74 percent of Americans polled in $20 \mathrm{II}$

${ }^{83}$ While the King holiday is an optional holiday, the number of employers giving a day off as a paid holiday continues to rise. Olivera Perkins, "Only 37\% of Employers Give Off Martin Luther King Day, but Number at All-Time High," i 5. Jan. 201 5, at www.cleveland.com/ business/index.ssf/2015/or/only_37_of_employers_give_off.html.

${ }^{84}$ Coretta Scott King, "The Making of a Holiday and Beyond," is April 1986, in Holiday Commission, 1986 Report II, n.p. See also Scott King, "Remarks Swearing in Ceremony for Members of Commission," I6 Sept. 1986, in Holiday Commission Records, Box 4.

85 Cf. Mary E. Stuckey, The President as Interpreter-in-Chief (Chatham, NJ: Chatham House Publishers, I 99 I); Michael Novak, Choosing Presidents: Symbols of Political Leadership (New Brunswick, NJ: Transaction Publishers, 1992).

${ }^{86}$ Cf. Drew D. Hansen, The Dream: Martin Luther King, Jr., and the Speech That Inspired a Nation (New York: Ecco, 2003), 219-22. 
believed that King's dream "has been realized or that major progress has been made." 87

In contrast, despite disapproving of governmental intervention, opinion polls also indicate that white racial attitudes have changed, supporting the principles of integration and equal treatment. ${ }^{88}$ Moreover, the Martin Luther King Day has also become a day of protest. As already pointed out in the introduction, an annual public debate has emerged about King's legacy, questioning the dominant narrative and its selective remembering. In fact, civil religion and its critical-prophetic function have in some instances actually raised awareness and helped in the protest against a deadlock for civil rights. ${ }^{89}$ Maybe civil religion's critical prophetic function can help "to make civil rights harder. Harder to celebrate as a natural progression of American values. Harder to cast as a satisfying morality tale. Most of all, harder to simplify, appropriate, and contain." $9 \circ$ And maybe this was one of the reasons why Cornel West chose to spend the day of the dedication of the Martin Luther King, Jr. Memorial in 20 I I not at the actual site but by protesting on the steps of the Supreme Court in support of the Occupy Wall Street movement: "We will not allow this day of Martin Luther King Jr.'s memorial to go by without somebody going to jail, because Martin Luther King would be here right with us."91

Yet as of now it seems that civil religion has done more harm than good. It has distorted and muted King's radical message of social change, rendering his call for political activism obsolete. As Kevin Bruyneel points out in his article on the Martin Luther King Memorial, the way King is remembered defines "the meaning and impact of the civil rights movement of the I950s and 1960s, and thus the status of race relations and race politics since that

${ }^{87}$ Jeffrey M. Jones, "Americans Divided on Whether King's Dream Has Been Realized," Gallup Politics, 26 Aug. 20II, at www.gallup.com/poll/I49201/Americans-DividedWhether-King-Dream-Realized.aspx.

${ }^{88}$ Cf. Lawrence D. Bobo and Ryan A. Smith, "From Jim Crow Racism to Laissez-Faire Racism: The Transformation of Racial Attitudes," in Wendy F. Katkin, Ned Landsman, and Andrea Tyree, eds., Beyond Pluralism: The Conception of Groups and Group Identity in America (Champagne Urbana: University of Illinois Press, 1998), I 82-220.

89 Cf. Ronald Smothers, "Bigotry's Persistence Noted as Dr. King Is Honored Nationwide," New York Times, i9 Jan. 1988, B3; David Savage, "Black Leaders Rebuke Reagan for TV Remarks," Los Angeles Times, I5 Jan. 1989, Part I, I, 22; Molly Sinclair, "King's Call to Action Sounded Anew," Washington Post, I6 Jan. I990, B I, B3.

$9^{\circ}$ Dowd Hall, "The Long Civil Rights Movement," I 235.

${ }^{91}$ Cornel West cited in John Nichols, "Why Cornel West Was Arrested in Memory of Martin Luther King Jr., in Support of Occupy Movement," The Nation, 17 Oct. 20 I I, at www.thenation.com/blog/I 64022/why-cornel-west-was-arrested-memory-mlk-supportoccupy-movement. 
time." 92 The Martin Luther King Day is still a young holiday. A way needs to be found to celebrate a symbol both of unity and of protest, an icon of progress but also of reform and radicalism. Otherwise, people will continue to spend the holiday fighting for the rights they already supposedly have.

\section{AUTHOR BIOGRAPHY}

Dr. Jana Weiß is Assistant Professor at the University of Münster (Germany), North American History Department. Her dissertation (Fly the Flag and Give Thanks to God: Zivilreligion an US-amerikanischen patriotischen Feiertagen, 1945-I9g2 (Trier: Wissenschaftlicher Verlag Trier, 2015); see also the anthology edited by Heike Bungert and Jana Weiß, Zivilreligion in den USA im 20. Jahrhundert (Frankfurt: Campus Verlag, 2017)) focussed on civil religion and US/American, patriotic holidays in the second half of the twentieth century. Her current project focusses on the history of beer in pre-Prohibition USA and its evolution from a German cultural asset to an Americanized mass product. In the 2015-16 academic year she was Visiting Fellow at the Max Kade Institute for German-American Studies at the University of Wisconsin-Madison, funded by the German Research Foundation.

92 Kevin Bruyneel, "The King's Body: The Martin Luther King Jr. Memorial and the Politics of Collective Memory," History and Memory, 26, I (2014), 75-108, 76. 